\title{
Kinerja dan Adaptasi Organisasi Pengelola Zakat (OPZ) di Provinsi DI Yogyakarta Pasca Judicial Review UU Zakat No. 23 Tahun 2011
}

\author{
Dedi Djubaedi \\ Selamet \\ M. Taufik Hidayatulloh
}

\begin{abstract}
Abstraks: DI Yogyakarta merupakan salah satu daerah yang memiliki potensi zakat yang cukup besar. Hal tersebut terjadi seiring dengan tumbuhnya kesadaran masyarakat kelas menengah muslim untuk menyalurkan dana amal mereka melalui lembaga-lembaga pengelola zakat. Untuk itu penting dilakukan penelitian "Kinerja dan Adaptasi Organisasi Pengelola Zakat (OPZ) di Provinsi DI Yogyakarta Pasca Judicial Review UU Zakat No. 23 Tahun 2011". Penelitian ini menggunakan pendekatan kualitatif, dalam bentuk Action Research (AR) modifikasi. Subjek penelitian adalah stakeholder zakat yang dipilih secara ditentukan. Hasil penelitian menunjukkan bahwa: (1) Keterbatasan SDM dan sarana prasarana yang dimiliki BAZNAS Provinsi DI Yogyakarta serta lemahnya keterlibatan dan dukungan dari pejabat di tingkat provinsi DI Yogyakarta membuat BAZNAS Provinsi belum dapat menjalankan tugas dan fungsinya secara optimal. (2) Lembaga-lembaga zakat di DI Yogyakarta yang belum berizin umumnya telah mempersiapkan diri dengan melakukan upaya ke arah legalisasi lembaga pengelola zakat sesuai UU Zakat No. 23 Tahun 2011, dengan pengajuan rekomendasi ke BAZNAS DI Yogyakarta akan tetapi struktur kepengurusan BAZNAS Provinsi DI Yogyakarta yang saat ini sedang dalam masa transisi dianggap menjadi kendala utama dalam proses pengajuan izin legalisasi LAZ. Walaupun di Yogyakarta tidak terdapat gejolak di antara pengelola LAZ pasca terbitnya UU No 23 tahun 2011, namun saat ini relasi antara BAZNAS dan LAZ belum terbangun secara efektifformal kelembagaan, sehingga masih terdapat kesenjangan antara BAZNAS dan LAZ baik dari segi kesefahaman maupun praktik pengelolaan zakat yang masih berjalan sendiri-sendiri.
\end{abstract}

Kata Kunci : LAZ, Judicial Review, UU Zakat.

Permalink/DOI: http://doi.org/10.15408/dakwahv22i1.12066

\section{Pendahuluan}

Zakat merupakan salah satu pilar dari lima pilar ${ }^{1}$ yang membentuk Islam. Zakat adalah ibadah maaliah ijtimaåiyyah² yang memiliki posisi strategis dan menentukan bagi pembangunan kesejahteraan umat. Zakat tidak hanya berfungsi sebagai suatu ibadah yang bersifat vertikal kepada Allah (hablumminallah), namun zakat juga berfungsi sebagai wujud ibadah yang bersifat horizontal / hablumminannaas (Hudayati dan Tohirin, 2010; Lubis et all, 2011). 3

Pengumpulan dan pemanfaatan zakat bertujuan untuk mewujudkan kesejahteraan masyarakat dan penanggulangan kemiskinan. Pengelolaan zakat sudah melembaga sejak lama dan terus berkembang sesuai dengan perkembangan masyarakat. Pada tahun 2011 bangsa Indonesia telah melahirkan hukum material dalam bentuk Undang-Undang Nomor 23 Tahun 2011 tentang Pengelolaan Zakat, sebagai pengganti Undang-Undang Nomor 38 Tahun 1999 tentang Pengelolaan Zakat. Pengelolaan zakat sebagaimana diatur dalam undang-undang meliputi kegiatan perencanaan, pengumpulan, pendistribusian dan pendayagunaan. 
Sebagai operasionalisasi, pemerintah mengeluarkan Peraturan Pemerintah RI Nomor 14 Tahun 2014 tentang Pelaksanaan Undang-undang Nomor 23 Tahun 2011 tentang Pengelolaan Zakat. Lebih jauh dari itu, untuk mengoptimalkan pengumpulan dan pemanfaatan zakat dalam rangka mewujudkan kesejahteraan masyarakat dan penanggulangan kemiskinan, maka pemerintah mengeluarkan Instruksi Presiden RI Nomor 3 Tahun 2014 tentang Optimalisasi Pengumpulan Zakat di Kementerian/Lembaga, Sekretariat Jenderal Lembaga Negara, Sekretariat Jenderal Komisi Negara, Pemerintah Daerah, Badan Usaha Milik Negara, dan Badan Usaha Milik Daerah melalui Badan Amil Zakat Nasional.

Dalam UU No. 23 Tahun 2011, terdapat perbedaan struktur institusi. Dalam upaya mencapai tujuan pengelolaan zakat, dibentuk Badan Amil Zakat Nasional (BAZNAS) yang berkedudukan di ibu kota negara, BAZNAS provinsi, dan BAZNAS kabupaten/kota. BAZNAS merupakan lembaga pemerintah nonstruktural yang bersifat mandiri dan bertanggung jawab kepada Presiden melalui Menteri. BAZNAS merupakan lembaga yang berwenang melakukan tugas pengelolaan zakat secara nasional.

Dalam rangka membantu BAZNAS dalam pelaksanaan pengumpulan, pendistribusian, dan pendayagunaan zakat, masyarakat dapat membentuk Lembaga Amil Zakat (LAZ). Pembentukan LAZ wajib mendapat izin Menteri atau pejabat yang ditunjuk oleh Menteri. LAZ wajib melaporkan secara berkala kepada BAZNAS atas pelaksanaan pengumpulan, pendistribusian, dan pendayagunaan zakat yang telah diaudit syariat dan keuangan. Dengan demikian, posisi LAZ tidak setara lagi dengan BAZ.

Sesuai dengan UU Zakat Nomor 23 Tahun 2011 tentang Pengelolaan Zakat Pasal 43 antara lain disebutkan bahwa BAZNAS dan BAZDA tetap menjalankan tugas sampai BAZNAS baru terbentuk. LAZ wajib menyesuaikan diri paling lambat 5 (lima) tahun terhitung sejak UndangUndang ini diundangkan. Undang-Undang ini berlaku sejak diundangkan pada tanggal 25 November 2011. Sehingga dengan demikian, terhitung mulai 25 November 2016 LAZ wajib menyesuaikan diri dengan UU 23 Tahun 2011 tersebut.

Konsekuensi penyempurnaan regulasi tersebut baik BAZNAS maupun LAZ, mereka harus mempersiapkan diri untuk menyesuaikan dengan peraturan perundangan yang berlaku. Perubahan mendasar mencakup berbagai persyaratan, antara lain : (1) kepengurusan pimpinan BAZNAS (nasional, provinsi dan kabupaten/kota); (2) LAZ berupa organisasi kemasyarakat Islam; (3) LAZ memiliki pengawas syariat; dan (4) terkait pembentukan perwakilan LAZ.

Pasca putusan Mahkamah Konstitusi (MK) terhadap judicial review UU Nomor 23 Tahun 2011, maka terdapat banyak hal yang harus dipersiapkan di antaranya adalah: (1) masih kurangnya sosialisasi oleh Kementerian Agama RI terkait dengan peraturan perundangan tentang pengelolaan zakat; (2) adanya peluang yang makin luas bertambahnya lembaga pengelola zakat tersebar di seluruh provinsi dan kabupaten/kota di seluruh Indonesia; (3) LAZ tingkat nasional yang telah dikukuhkan (mendapat izin) sebanyak 18, namun banyak lembaga pengelola zakat yang 
tidak mendapat izin dari pemerintah tetap menjalankan operasinya; (4) BAZNAS provinsi dan kab/kota seluruhnya belum terbentuk (meliputi: kepengurusan/kepemimpinan, sumber-sumber, dan infrastruktur) di mana seluruh pengajuan pendirian LAZ ditangani oleh BAZNAS; (5) belum siapnya seluruh pemangku kepentingan (stakeholders) untuk melaksanakan peraturan perundangan yang berlaku.

Berdasarkan berbagai permasalahan di atas, maka perlu dilakukan penelitian untuk melihat sejauhmana organisasi pengelola zakat (OPZ) mempersiapkan / menyesuaikan diri untuk melakukan tugas, serta menyelenggarakan fungsinya dalam pengelolaan zakat sesuai dengan perundang-undangan yang berlaku. Untuk hal tersebut Pusat Penelitian Bimas Agama dan Layanan Keagamaan, pada tahun 2015 melakukan penelitian mengenai Restrukturisasi Organisasi Pengelola Zakat (OPZ) di Provinsi DI Yogyakarta Pasca Judicial Review UU Zakat No. 23 Tahun 2011.

Berdasarkan latar belakang ini, maka permasalahan yang akan dikaji dalam penelitian ini adalah Bagaimana BAZNAS (provinsi, kabupaten/kota) dan LAZ (nasional, provinsi, kabupaten/kota) melaksanakan pengelolaan zakat (pengumpulan, pendistribusian, pendayagunaan dan pelaporan)? Bagaimana BAZNAS (Provinsi, Kabupaten/Kota) dan LAZ (nasional, provinsi, kabupaten/kota), sebagai Organisasi Pengelola Zakat (OPZ) mempersiapkan / menyesuaikan diri untuk melakukan tugas, serta menyelenggarakan fungsinya dalam pengelolaan zakat sesuai Undang-Undang Nomor 23 Tahun 2011 tentang Pengelolaan Zakat?

Tujuan yang ingin dicapai dalam penelitian ini, yaitu untuk; menganalisis tugas dan fungsi BAZNAS (provinsi, kabupaten/kota) dan LAZ (nasional, provinsi, kabupaten/kota) dalam pengelolaan zakat (pengumpulan, pendistribusian, pendayagunaan dan pelaporan), menganalisis upaya BAZNAS (provinsi, kabupaten/kota) dan LAZ (nasional, povinsi, kabupaten/kota), dalam menyesuaikan diri sesuai Undang-Undang Nomor 23 Tahun 2011 tentang Pengelolaan Zakat.

\section{Metode Penelitian}

Penelitian ini merupakan penelitian kualititatif dengan menggunakan Action Research (AR) modifikasi. Action Research (AR) merupakan salah satu jenis riset sosial terapan untuk menemukan salah satunya solusi praktis dari suatu permasalahan. ${ }^{4}$ Ada beberapa alasan yang mendorong peneliti menggunakan metode Action Research, yaitu : Peneliti dan pihak terkait dapat secara bersama-sama dalam mengidentifikasikan masalah, mencari penyebab masalah dan intervensi atas permasalahan yang terjadi. Terbentuknya pemahaman bersama antara peneliti dan pihak terkait akan meningkatkan kesadaran kolektif, sehingga akan lebih memudahkan jika terjadi perubahan sesuatu apakah terkait sistem ataupun metode. Misalnya sistem penghimpunan dan penyaluran dana ataupun data base Mustahik dan Muzaki.

Penelitian ini mengikuti tahapan penelitian action research sebagaimana dikemukakan Davison, Martinsons dan Kock (2004)5, yaitu mulai dari : melakukan diagnosa (diagnosing), 
membuat rencana tindakan (action planning), melakukan tindakan (action taking), melakukan evaluasi (evaluating), dan pembelajaran (learning).

Pada penelitian ini, tahapan-tahapan pada sebuah penelitian action research di atas dimodifikasi hanya meliputi dua tahapan dari lima tahapan yang ada, yaitu : Melakukan diagnosa terhadap langkah utama stakeholder zakat (Pemerintah, OPZ) dalam penyesuaian terhadap ketentuan UU 23/2011 terkait organisasi pengelola zakat dalam melakukan penghimpunan dan pendistribusiastilah usulan pemikiran terhadap persoalan yang sudah din serta pemberdayaan dana zakat. Selanjutnya membuat rencana tindakan (action planning) yang dalam hal ini dimodifikasi dengan idiagnosa pada tahapan pertama.

ikemukakan oleh Miles dan Huberman, yakni reduksi data (pemilahan, pemusat perhatian), penyajian (display) data dan penarikan kesimpulan.

\section{Pembahasan}

\section{Profil Provinsi Daerah Istimewa Yogyakarta}

Daerah Istimewa Yogyakarta adalah salah satu provinsi yang terletak di pulau Jawa bagian tengah. Daerah Istimewa Yogyakarta di bagian selatan dibatasi Lautan Indonesia, sedangkan di bagian timur laut, tenggara, barat, dan barat laut dibatasi oleh wilayah provinsi Jawa Tengah yang meliputi : Kabupaten Klaten di sebelah Timur Laut, Kabupaten Wonogiri di sebelah Tenggara, Kabupaten Purworejo di sebelah Barat dan Kabupaten Magelang di sebelah Barat Laut.

Tabel 1. Jumlah Penganut Agama di DI Yogyakarta Tahun 2013

\begin{tabular}{|c|c|c|c|c|c|c|c|c|}
\hline No & Kab/Kota & Islam & $\begin{array}{c}\text { Kriste } \\
\mathbf{n}\end{array}$ & $\begin{array}{c}\text { Katol } \\
\text { ik }\end{array}$ & Hindu & Budha & $\begin{array}{r}\text { Khong } \\
\text { hucu }\end{array}$ & Jumlah \\
\hline 1 & Kulonprogo & $4 \circ 3 \cdot 524$ & 6.076 & 20.201 & 31 & 634 & 1 & 430.467 \\
\hline 2 & Bantul & $873 \cdot 768$ & 12.489 & 27.710 & $77^{1}$ & 235 & 5 & 914.998 \\
\hline 3 & $\begin{array}{l}\text { Gunungkidu } \\
\text { l }\end{array}$ & 819.987 & $15 \cdot 375$ & 15.804 & 1.390 & 555 & 576 & 853.687 \\
\hline 4 & Sleman & $923 \cdot 322$ & 40.913 & $\begin{array}{c}66.40 \\
8\end{array}$ & 1941 & 1.002 & - & 1.033 .686 \\
\hline 5 & Yogyakarta & $335 \cdot 3^{89}$ & 26.478 & $43 \cdot 196$ & $55^{2}$ & $1.3^{66}$ & 26 & 407.007 \\
\hline \multicolumn{8}{|c|}{ Jumlah } & 3.639 .745 \\
\hline
\end{tabular}

DI Yogyakarta tercatat memiliki luas $3.185,80 \mathrm{~km}^{2}$ atau 0,17 persen dari luas Indonesia (1.860.359,67 km²), merupakan provinsi terkecil setelah Provinsi DKI Jakarta (664.01 km²). Secara administratif Provinsi Daerah Istimewa Yogyakarta terdiri dari empat kabupaten dan satu kota dengan jumlah 78 kecamatan dan 438 kelurahan/desa. Berdasarkan hasil proyeksi penduduk dari SP 2010, jumlah penduduk DI Yogyakarta tahun 2013 tercatat 3.639.745 jiwa, dengan persentase jumlah penduduk laki-laki 49,40 persen dan penduduk perempuan 50,60 persen. Menurut daerah, persentase penduduk kota mencapai 66,09 persen dan penduduk desa mencapai 
33,91 persen. Sementara dilihat dari jumlah pemeluk agama di DI Yogyakarta dapat dilihat pada tabel 1.

Dari tabel 1 diketahui bahwa prosentase penganut agama di DI Yogyakarta adalah 92,20 persen pemeluk agama Islam, sebanyak 4,76 persen pemeluk agama Katholik, Pemeluk agama Kristen 2,78 persen, Hindu 0,13 persen, dan Budha 0,10 persen. Sehingga dengan demikian, masyarakat DI Yogyakarta mayoritas beragama Islam.

\begin{tabular}{|c|c|c|c|c|c|c|c|}
\hline \multirow{2}{*}{\multicolumn{2}{|c|}{$\begin{array}{c}\text { Tempat } \\
\text { Peribadatan }\end{array}$}} & \multicolumn{5}{|c|}{ Kabupaten/Kota } & \multirow[b]{2}{*}{ DI Yogyakarta } \\
\hline & & $\begin{array}{l}\text { Kulon } \\
\text { progo }\end{array}$ & Bantul & Gunung & Sleman & $\begin{array}{l}\text { Yogya } \\
\text { karta }\end{array}$ & \\
\hline \multicolumn{8}{|c|}{ Islam } \\
\hline 1 & Masjid & 1.079 & 1.685 & 1.824 & 1.982 & 492 & 7.062 \\
\hline 2 & Musolla & $45^{8}$ & 1.132 & 701 & 666 & 465 & 3.422 \\
\hline \multicolumn{8}{|c|}{ Kristen } \\
\hline 1 & Gereja & 21 & 28 & 45 & 60 & 41 & 195 \\
\hline 2 & $\begin{array}{l}\text { Rumah } \\
\text { Kebaktian }\end{array}$ & 12 & 7 & 3 & 9 & 2 & 33 \\
\hline \multicolumn{8}{|c|}{ Katolik } \\
\hline 1 & Gereja & 4 & 3 & 3 & 15 & 8 & 33 \\
\hline 2 & Kapel & 37 & 43 & 42 & 53 & 42 & 217 \\
\hline \multicolumn{8}{|c|}{ Hindu } \\
\hline 1 & Pura & - & 4 & 15 & 4 & 1 & 24 \\
\hline 2 & Sanggar & - & 1 & 1 & 1 & - & 3 \\
\hline \multicolumn{8}{|c|}{ Budha } \\
\hline 1 & Wihara & 6 & 1 & 9 & 3 & 6 & 25 \\
\hline 2 & Cetya & 1 & - & - & - & 1 & 2 \\
\hline \multicolumn{8}{|c|}{ Khonghucu } \\
\hline 1 & Klenteng & - & - & - & - & 2 & 2 \\
\hline & Jumlah & 1.618 & 2.904 & 2.643 & 2.793 & 1.060 & 11.018 \\
\hline
\end{tabular}

Sejalan dengan komposisi sebagaimana tabel 2, jumlah tempat peribadatan yang tersebar di Provinsi DIYogyakarta juga didominasi oleh tempat ibadah umat Islam berupa masjid dan mushola yang tercatat sebanyak 95,15 persen. Kemudian rumah ibadah Katholik dan Kristen masing-masing 2,27 persen dan 2,07 persen serta tempat ibadat umat Hindu dan Budha masingmasing 0,25 persen dan 0,25 persen. ${ }^{6}$

Sedangkan jumlah pemuka agama yang memberikan pelayanan keagamaan kepada umat masing-masing agama di wilayah provinsi DI Yogyakarta dapat dilihat dalam tabel 3. Pemuka agama Islam7 ${ }^{7}$ paling banyak berasal dari Sleman. Bikhu sebagai pemuka agama dari Budha paling banyak berasal dari Gunungkidul dan Kulonprogo. Adapun pemuka agama dari Kristen atau

Sementara itu, menurut catatan Kantor Kanwil Kementerian Agama Provinsi DI Yogyakarta, pada tahun 2015 terdapat beberapa Organisasi Pengelola Zakat (OPZ) atau Lembaga Zakat (LAZ) yang masuk dalam data Kanwil Kementerian Agama Provinsi DI Yogyakarta, baik yang berbentuk BAZNAS maupun LAZ. Di antara organisasi atau lembaga tersebut di luar BAZNAS Provinsi terdapat 5 BAZNAS Kab/Kota, dan 21 LAZ yang tersebar di seluruh wilayah DI Yogyakarta. 

Tabel 3. Jumlah Pemuka Agama di DI Yogyakarta Tahun 2013

\begin{tabular}{|c|c|c|c|c|c|c|c|}
\hline \multirow[b]{2}{*}{ Pemuka Agama } & \multicolumn{5}{|c|}{ Kabupaten/Kota } & \multirow{2}{*}{$\begin{array}{c}\text { DI } \\
\text { YOGYA } \\
\text { KARTA }\end{array}$} & \multirow[b]{2}{*}{ Jumlah } \\
\hline & $\begin{array}{l}\text { Kulon } \\
\text { progo }\end{array}$ & $\begin{array}{c}\text { Bantu } \\
1\end{array}$ & $\begin{array}{c}\text { Gunung } \\
\text { kidul }\end{array}$ & Sleman & $\begin{array}{l}\text { Yogya } \\
\text { karta }\end{array}$ & & \\
\hline Islam/Ulama & 766 & 690 & 360 & 792 & 545 & - & 3.153 \\
\hline Kristen/Pendeta & 1 & 1 & 1 & 5 & 5 & - & 13 \\
\hline Katolik/Pastur & 7 & 7 & 5 & 34 & 25 & - & 78 \\
\hline Hindu/Pedande & 3 & 16 & 20 & 18 & 10 & 17 & 86 \\
\hline Budha/Bikhu & 40 & 3 & 47 & 24 & 20 & - & 134 \\
\hline
\end{tabular}

Menurut keterangan narasumber Juni A. Dwi Utomo selaku pengurus Forum Zakat (FOZ) DI Yogyakarta, saat ini lembaga pengelola zakat di Provinsi DI Yogyakarta yang masuk dalam keanggotaan FOZ DI Yogyakarta ada sekitar 20 LAZ, menurutnya karena ada LAZ yang aktif dan ada yang tidak, jika dikelompokkan dari 20 lembaga itu ada 4 kategori' ${ }^{8}$, yaitu : LAZ-LAZ besar yang sudah mempunyai SK pusat dari Kementrian Agama, beberapa LAZ ini berdiri sekitar tahun 1999/1998 seperti Dompet Dhuafa, Rumah Zakat, PKPU, LAZ NU, LAZ MU, Aksi Cepat Tanggap (ACT) dan Baitul Maal Muamalat (BMM). Penghimpunan dana zakat di Yogyakarta untuk LAZLAZ yang besar ini sekitar 500 juta sampai 1 Milyar per bulan.

1. LAZ yang agak besar tapi belum memiliki SK Kementerian Agama seperti DPUDT, PPPA, Yatim Mandiri, Yatim Dhuafa dan Baitul Maal Hidayatullah. Pengumpulan LAZ-LAZ yang menengah ini sekitar 200 sampai 300 juta per bulan.

2. LAZ lokal Yogyakarta seperti LAZIS YBW UII, LAZIS Masjid Syuhada, Yayasan Pusat Zakat Nasional dan Lumbung Zakat. Penghimpunan dana LAZ-LAZ lokal sekitar 100 dan 200 jutaan.

3. LAZ yang bersifat personal seperti Panti Asuhan, Pesantren, Sekolah dan Baitul Maal wa Tamwil yang menghimpun dana zakat.

\section{Kinerja Badan Amil Zakat Nasional (BAZNAS) Provinsi DI Yogyakarta}

BAZNAS DI Yogyakarta yang ada saat ini pada mulanya adalah Badan Amil Zakat Infaq dan Sadaqah (BAZIS) di lingkungan Kantor Wilayah Kementerian Agama Propinsi DI Yogyakarta yang saat itu masih bernama Kantor Wilayah Departemen Agama.

BAZIS DI Yogyakarta didirikan berdasarkan Keputusan Kepala Kantor Wilayah Departemen Agama No. 25/KPTS/1989 tanggal 1 Mei 1989. Tujuan dibentuknya BAZIS adalah untuk menampung dan mengelola zakat yang ada di lingkungan Kantor Wilayah Departemen Agama. Pada perkembangan selanjutnya dengan keluarnya keputusan bersama Menteri Dalam Negeri dan Menteri Agama Republik Indonesia No. 29 tahun 1991 tentang pembinaan BAZIS, operasional BAZIS ini diperluas ke lingkungan pemerintah daerah Provinsi Daerah Istimewa 
Yogyakarta. Keberadaannya itu kemudian dikukuhkan menjadi BAZIS DI Yogyakarta. Pengukuhan ini berdasarkan pada keputusan Gubernur No. 9/KPTS/1992 tanggal 15 juni 1992.

Pada tahun 1996 keberadaan BAZIS DI Yogyakarta ini semakin sempurna dengan keluarnya SK Gubernur DI Yogyakarta No. 9/KPTS/1996 tanggal 12 Januari 1996. Berdasarkan SK ini telah dikukuhkan kepengurusan BAZIS DI Yogyakarta, dan kemudian dilantik pada 9 Februari 1996 di Pagelaran Kraton Yogyakarta. Kemudian dengan dikeluarkanya Undang-Undang Republik Indonesia No 38 Tahun 1999 tentang Pengelolaan Zakat, nama BAZIS ini berubah menjadai BAZDA (Badan Amil Zakat Daerah) DI Yogyakarta. Seiring dengan disempurnakan UndangUndang No. 23 Tahun 2011, BAZDA berubah menjadi BAZNAS (Badan Amil Zakat Nasional) DI Yogyakarta.

Saat ini kepengurusan BAZNAS DI Yogyakarta dalam masa transisi menunggu terbentuknya struktur kepengurusan yang baru, yang nama-namanya telah diajukan untuk mendapat rekomendasi dari BAZNAS Pusat. Untuk menjalankan roda administrasi dan melakukan pelayanan, BAZNAS DI Yogyakarta saat ini dikelola oleh ketua harian dibantu oleh 4 orang staf kepengurusan yang lama.

Badan Amil Zakat Nasional (BAZNAS) Provinsi DI Yogyakarta berkantor di komplek Perkantoran Kantor Wilayah Kementerian Agama Provinsi DI Yogyakarta Jl. Sukonandi No. 8 Yogyakarta, Phone/fax : 0274 587062, Website: DI Yogyakarta.baznas.go.id, Facebook : Baznas Daerah Istimewa Yogyakarta, Twitter: @Baznas DI Yogyakarta, Email: baznasprov.DI Yogyakarta@baznas.-or.id.

Sebagai lembaga publik yang dibentuk oleh pemerintah yang mendapatkan kewenangan untuk mengumpulkan, mendistribusikan dan mendayagunakan dana zakat, infaq dan shodaqoh, BAZNAS DI Yogyakarta telah melakukan berbagai strategi untuk melakukan hal-hal tersebut. Sumber utama pengumpulan dana yang dikelola oleh BAZNAS DI Yogyakarta berasal dari dana zakat, infaq dan shodaqoh yang mayoritas berasal dari para Pegawai Negeri Sipil (PNS) yang berdinas pada SKPD, BUMD, maupun Instansi Kedinasan yang ada di lingkungan Pemerintah Daerah provinsi DI Yogyakarta, meski demikian BAZNAS DI Yogyakarta tetap memberikan pelayanan kepada masyarakat umum yang ingin menyampaikan zakat, infaq dan shodaqohnya lewat BAZNAS DI Yogyakarta.

Tabel 4. Peneriman dan Penyaluran Zakat, Infaq dan Shodaqoh

BAZNAS DI Yogyakarta Tahun 2011 s.d 2014

\begin{tabular}{|c|c|c|c|c|}
\hline & 2011 & 2012 & 2013 & 2014 \\
\hline Penerimaan & 371.233 .961 & 705.703 .491 & $\begin{array}{c}1.122 .000 .74 \\
5\end{array}$ & 1.175 .648 .643 \\
\hline Penyaluran & 191.371 .400 & 240.730 .800 & 629.242 .600 & 1.084 .105 .182 \\
\hline
\end{tabular}

Disampaikan oleh narasumber Muhammad Yusuf Wibisono, selaku Kabid Pendistribusian dan Pendayagunaan BAZNAS DI Yogyakarta, bahwa ada beberapa faktor yang menyebabkan belum optimalnya pengumpulan dana zakat, infak dan sodakoh pada tingkat BAZNAS Provinsi DI 
Yogyakarta. Di antaranya pertama, dana yang diambil dari setiap PNS masih belum berbentuk zakat $100 \%$, tetapi umumnya masih dalam kategori infaq dan shodaqoh yang jumlah penarikannya disesuaikan dengan tingkat golongan kepangkatan; kedua, dana zakat infaq dan shodaqoh yang dihimpun oleh SKPD, BUMD maupun Instansi Kedinasan di lingkungan Pemerintah Daerah Provinsi DI Yogyakarta, belum seluruhnya diserahkan kepada BAZNAS DI Yogyakarta, akan tetapi hanya 40\%, sementara 60\% dikelola oleh masing-masing SKPD sendiri; ketiga, minimnya dukungan moril maupun materil dari pejabat pemerintah provinsi DI Yogyakarta, baik berupa surat keputusan atau surat edaran yang mengatur tentang pemotongan dana zakat bagi PNS di lingkungan Pemerintah Daerah Provinsi DI Yogyakarta, maupun bantuan sarana dan prasarana. Dan ironisnya, dalam hal optimalisasi pengumpulan zakat, infaq dan shodaqoh justru BAZNAS Provinsi DI Yogyakarta yang paling rendah dibandingkan BAZNAS tingkat Kota maupun Kabupaten yang ada di Provinsi DI Yogyakarta. ${ }^{9}$

Dalam pendayagunaan dan penyaluran dana zakat, infaq dan shodaqoh yang dihimpun oleh BAZNAS DI Yogyakarta, disalurkan dalam bentuk bantuan fakir/miskin, bantuan pembangunan dan renovasi tempat ibadah, bantuan ekonomi produktif, bantuan pendidikan, bantuan kesehatan, bantuan musafir, bantuan yatim piatu, bantuan dakwah dan pembinaan muallaf, serta pengadaan sarana dan prasarana yang direalisasikan dalam 5 program yaitu :

1. Program DI Yogyakarta Sejahtera

Program ini adalah program untuk mensejahterkan para Mustahik/Dhuafa di wilayah Yogyakarta yang berbentuk Bantuan Ekonomi Produktif (Modal Usaha, Peralatan Usaha, Bina Usaha). Kriteria atau Syarat untuk memperoleh bantuan tersebut adalah : Surat Permohonan dan Proposal (Data Usaha, bentuk usaha, alamat usaha, mulai mendirikan usaha, jumlah tenaga kerja, dsb) mengetahui Camat atau Kepala KUA tempat usaha dijalankan; Pengajuan berlaku untuk jangka waktu1 (satu) tahun; dan Survey oleh pegawai BAZNAS tentang kelayakan bantuan.

Di samping bantuan Ekonomi produktif dilakukan juga program Bantuan Bedah Rumah. Program ini berbentuk pemberian bantuan pembangunan atau renovasi rumah bagi para dhuafa. Kriteria atau Syarat bagi mustahik yang akan memperoleh bantuan bedah rumah, adalah : Surat Permohonan dan Proposal mengetahui Camat atau Kepala KUA tempat renovasi rumah dilaksanakan; Diajukan oleh lembaga (sosial maupun agama); Pengajuan berlaku untuk satu kali pengajuan; dan Survey oleh pegawai BAZNAS tentang kelayakan bantuan.

2. Program DI Yogyakarta Cerdas

Program ini berbentuk Bantuan Pendidikan Siswa Kurang Mampu biasa diperuntukan bagi siswa yang menunggak tanggungan atau untuk pengambilan ijazah yang ditahan oleh sekolah karena alasan tunggakan pembiayaan, serta Bantuan Pendidikan yang bersifat kolektif berkoordinasi dengan Dinas Pendidikan dan Kebudayaan.

3. Program DI Yogyakarta Sehat 
Program ini berbentuk bantuan pengobatan dan santunan kesehatan bagi para dhuafa secara umum yang dilakukan dengan bekerja sama dengan lembaga kesehatan.

4. Program DI Yogyakarta Peduli

Program ini berbentuk Santunan Sakit bagi para Pegawai di lingkunagn Instansi Pemerintah daerah DI Yogyakarta seperti PNS Golongan I, II, III, IV dan Pejabat Struktural dan Fungsional, serta anak dari Keluarga PNS (yang tidak masuk ASKES).

5. Program DI Yogyakarta Taqwa

Program ini berbentuk bantuan pembangunan atau renovasi tempat ibadah (Masjid/Musholla/Langgar) dan Madrasah. Serta Bantuan Syiar Islam yang meliputi jenis kegiatan syiar keagamaan (syiar Islam), seperti: Syiar Billisan, Syiar Bilhal, Pengajian/Majelis Taklim, Pendidikan Al-Qur'an dan yang sejenis, Bhakti Sosial, Santunan/Bantuan bagi warga miskin dan sejenis.

Sebagai lembaga pengelola dana publik yang diberikan amanah menerima dan menyalurkan dana zakat, infaq dan shodaqoh secara profesional dari masyarakat, BAZNAS DI Yogyakarta menyampaikan laporan keuangan secara berkala setiap bulan, baik melalui laporan bulanan kepada Gubernur DI Yogyakarta, Kepala Kanwil Kementerian Agama DI Yogyakarta, maupun kepada masyarakat luas melalui website DI Yogyakarta.baznas.go.id ataupun melalui brosur, pamflet yang disebarkan pada event-event tertentu seperti pengajian rutin bulanan yang diselenggarakan Pemerintah DI Yogyakarta.

Dalam hal kinerja sebagai lembaga pembina LAZ di wilayah DI Yogyakarta, BAZNAS Provinsi mendapatkan respon positif dari LAZ. Hal ini diakui oleh Yusuf Wibisono bahwa hubungan Baznas dengan LAZ yang ada di DI Yogyakarta ini tidak ada masalah, cuma secara lembaga LAZ itu minta dihargai atau di uwongke, kita sebagai Baznas atau Kementrian Agama sebaiknya mendatangi LAZ satu persatu. Kalau menanyakan kegiatan atau laporan itu pada saat ketemu yang kedua kalau ketemu yang pertama itu semacam perkenalan mereka kita uwongkan. karena secara resmi kita belum pernah mendatangi satu persatu. ${ }^{10}$

\section{Kinerja LAZIS Yayasan Badan Wakaf Universitas Islam Indonesia (LAZIS YBW UII)}

Salah satu upaya nyata yang dilakukan oleh Universitas Islam Indonesia (UII) sebagai instritusi perguruan tinggi islam yang cukup tua di Indonesia adalah dengan mengimplementasikan nilai-nilai zakat sebagai salah satu pilar pembangunan umat. LAZIS YBW UII sebagai lembaga pengumpul dan pengelola dana zakat yang dibentuk oleh UII, berdiri pada tahun 2004 yang pada awalnya bernama LAZIS UII berada di bawah struktur Rektorat Universitas Islam Indonesia (UII) Yogyakarta yang ditetapkan melalui SK. Gubernur DI Yogyakarta No. 37/KEP/2005 yang dipimpin oleh seorang Direktur, kemudian pada tanggal 13 November 2014 terjadi perubahan struktur kelembagaan LAZIS UII menjadi berada di bawah Yayasan Badan Wakaf UII dan dipimpin oleh seorang Ketua dan berubah nama menjadi LAZIS YBW UII. 
Menurut keterangan Drs. H. M. Sularno, MA selaku ketua LAZIS YBW UII, perubahan struktur kelembagaan tersebut bertujuan agar LAZIS YBW UII dapat lebih berkiprah, dapat lebih memberi manfaat dan lebih menasional. Menurut pengakuannya, untuk ukuran LAZ-LAZ yang dikelola oleh perguruan tinggi di wilayah DI Yogyakarta, LAZIS YBW UII bisa dikatakan berada paling depan. ${ }^{11}$

Visi yang dikembangkan oleh LAZIS YBW UII adalah : "Terwujudnya Lembaga Amil Zakat Infaq dan Shodaqoh Yayasan Badan Wakaf Universitas Islam Indonesia yang Amanah dan Profesional untuk kemaslahatan umat sebagai perwujudan pilar Islam yang rahmatan lil 'alamin”. Dengan membawa Misi : Meningkatkan kultur LAZIS YBW UII yang amanah dan professional; Membentuk Sumber Daya Insani/Masyarakat Muslim Dhuafa yang berkualitas, berakhlak mulia, trampil dan cerdas; Membangun kemandirian dan kesejahteraan umat; dan Memfasilitasi pembayar zakat, infaq dan shodaqoh internal dan eksternal UII untuk mengimplementasikan syariat Islam.

Sebagai Lembaga pengelola dana zakat, infaq dan shodaqoh, LAZIS YBW UII juga memiliki beberapa Kebijakan Strategis, yaitu ; Membangun kultur lembaga yang amanah dan profesional melalui transparansi akuntabilitas publik dan program-program kemitraan dengan elemen masyarakat; Menjadikan program pendidikandan pelatihan masyarakat Islam dhuafa sebagai program utama; Turut berperan dalam pemberdayaan ekonomi, dakwah dan kesehatan umat Islam; Menjamin terlaksananya pengumpulan, penyaluran dan pendayagunaan ZIS dari pembayar zakat, infaq dan shodaqoh ke mustahiq secara syar’i.

Adapun Fokus Program Utama yang dikembangkan oleh Organisasi Pengelola Zakat ini adalah : Peningkatan kualitas pendidikan umat; Pember-dayaan ekonomi, sosial dan dakwah bagi umat Islam; Optimalisasi fundraising melalui program-program yang kreatif dan inovatif dan saling memberi manfaat.

\section{Program Fundraising/Penggalangan Dana}

Program ini merupakan proses mempengaruhi masyarakat atau para muzakki, baik sebagai individu maupun sebagai lembaga, untuk menyerahkan sumbangan dana baik berupa zakat, infaq maupun shodaqoh kepada LAZIS YBW UII. Para muzakki yang menjadi target sumber pengumpulan dana zakat, infaq dan shodaqoh yang utama adalah para dosen dan karyawan di lingkungan UII yang sebelumnya telah diperkuat dengan SK Rektor UII No. 1724/Rek/30/BAU/XI/2001 tanggal 30 November 2001 tentang Penunaian Zakat Profesi bagi dosen dan karyawan UII berupa potongan gaji untuk zakat sebesar 2,5\%. Bagi individu yang telah mencapai nisab, pemotongan 2,5\% tersebut dianggap sebagai zakat, sementara bagi yang belum mencapai nisab dianggap sebagai infaq atau shodaqoh.

Selain melalui pemotongan gaji dosen dan karyawan, dilakukan juga Program Optimalisasi Kotak Infaq, yaitu upaya pengumpulan dana yang bersifat pasif melalui kotak-kotak infaq yang 
tersebar pada masjid-masjid yang ada di lingkungan kampus-kampus UII. Upaya tersebut dilakukan melalui inventarisasi, pengawasan dan pengumpulan dana dari kotak infaq bekerjasama dengan para relawan LAZIS.

Dalam menjalankan amanat para muzaki dan dermawan, LAZIS YBW UII telah mengelola dana zakat, infak dan sodakoh secara profesional dan menyalurkan dana tersebut melalui pengembangan berbagai program-program unggulan seperti :

\section{Program Beasiswa Prestasi}

Program tersebut merupakan bentuk pendistribusian zakat produktif berupa pemberian beasiswa bagi anak dhuafa berprestasi dari tingkat SD, SMP dan SMA di wilayah Yogyakarta. Siswa siswi peserta program ini akan memperoleh beasiswa tidak terputus mulai dari tingkat SD, SMP hingga lulus SMA/SMK dengan memenuhi standar yang ditetapkan oleh LAZIS YBW UII.

Keberadaan Program Beasiswa Prestasi LAZIS YBW UII telah berlangsung kurang lebih 8 tahun dan telah meluluskan ratusan siswa siswi dhuafa berprestasi. Adapun jumlah dana zakat yang didistribusikan kepada siswa siswi dhuafa berprestasi tahun 2015 ini sebesar Rp. 350.000 untuk tingkat SD, Rp. 550.000 untuk tingkat SMP, dan Rp. 650.000 untuk tingkat SMA, yang dibayarkan tiap semester. Jumlah siswa siswi dhuafa berprestasi yang diberiakan beasiswa pada tahun 2015 ini sebanyak 283 orang.

Selain bantuan finansial juga dilakukan pembinaan untuk mengem-bangkan diri siswa siswi berupa program menghafal surat-surat pendek dalam Al Qur'an (Juz Amma) untuk tingkat SD dan SMP, penyelenggaraan kegiatan dakwah remaja SATSON (Saturday Sonten), Training Motivasi, Enterpreneur, dan Scince Adventur (Studi Tour).

\section{Program Galang TPA}

Program ini untuk mendistri-busikan zakat dengan sasaran asnaf fi sabilillah, khusunya para para ustadz dan ustadzah TPA di wilayah DI Yogyakarta. Selain itu program ini dapat berkembang untuk mendorong dan memajukan kegiatan TPA. Ada 5 layanan yang digulirkan, yaitu program santunan Ustadz dan Ustadzah TPA, program training Ustadz dan Usatadzah TPA, program bank Ustadz dan Ustadzah TPA, program bantuan sarana dan prasaran TPA, dan program pendampingan TPA.

\section{Program Galang MI}

Program tersebut guna mem-bantu para guru Madrasah Ibtidaiyah (MI) Honorer yang bergaji Rp.75.00o hingga Rp.300.00o per bulan. Jumlah guru MI yang direkrut sebanyak 104 guru MI dari wilayah Yogyakarta. Syarat untuk menjadi peserta program tersebut adalah guru MI non PNS dan non Sertifikasi yang telah mengajar minimal 1 tahun. Selanjutnya para guru tersebut akan memperoleh bantuan insentif sebesar Rp. 300.00o selama 1 tahun.

Di samping pemberian insentif dana bulanan, untuk meningkatkan kualitas dunia pendidikan Madrasah Ibtidaiyah, LAZIS YBW UII juga melakukan pembinaan kepada peserta program Galang MI berupa pelatihan yang dilaksanakan setiap 1 bulan sekali bekerjasama dengan ELSAP, yaitu sebuah lembaga yang concern di bidang pelatihan para guru. 
Pada Program Galang Madrasah Ibtidaiyah tahun 2014 telah dipilih 3 Madrasah Ibtidaiyah sebagai peserta program yang dinyatakan lolos dan memenuhi kriteria yang ditetapkan oleh LAZIS YBW UII yaitu MI Muh. Kenteng Kenteng, Demangrejo Sentolo Kulon Progo, MI YAPPI Doga Doga Nglanggeran Patuk Gunung Kidul, dan MI Al Muhsin II Meijing Bangunjiwo Kasihan Bantul. Bentuk program kepada Madrasah tersebut berupa membangun kemandirian untuk membentuk jaringan dengan pihak luar dalam upaya mengenalkan dan mengembangkan MI. Melalui kegiatan PSM (Peran Serta Masyarakat), peserta diminta me-rancang program-program yang melibatkan steakholders (orang tua siswa, alumni, pemerintah, perusahaan dan lain sebagainya), selanjutnya tim LAZIS YBW UII akan memberikan penilaian, masukan dan evaluasi terhadap program yang dibuat dan dijalankan oleh peserta program.

\section{Program Rumah Prestasi dan Beranda Keluarga LAZIS YBW UII.}

Bangunan tersebut pada awalnya merupakan gudang yang kemudian oleh LAZIS YBW UII dijadikan sebagai tempat kegiatan bimbingan belajar, dan merupakan rumah motivasi dan perubahan bagi masyarakat yang ada di Dusun Dekso Kecamat Banjar Arum Kabupaten Kulon Progo. Adapun layanan yang diberikan berupa bimbingan belajar gratis bagi dhuafa setiap 3 kali dalam seminggu. Setiap 2 bulan sekali mereka juga ditempa dalam kegiatan Mabit Super Camp di lokasi rumah prestasi LAZIS YBW UII.

Selain kegiatan untuk bimbingan belajar gratis juga dikembangkan kegiatan parenthing $c l u b$ atau pengajian bagi para orang tua siswa yang dilakukan setiap 2 bulan sekali. Program Parenthing club atau pengajian bagi para orang tua siswa bertujuan untuk menjalin tali silaturrahmi antar orang tua serta untuk merubah mindset dalam mendidk anak serta menerapkan dan menguatkan pendidikan dalam keluarga. Program ini bekerjasama dengan lembaga PUSKAGA (Pusat Kajian Anak dan Keluarga) Fakultas Psikologi UII. Materi yang disampaikan biasanya untuk memotifasi dan memberi pengetahuan tentang pengasuhan anak dan remaja secara islami.

6. Program Bantuan Logistik/Pemakanan bagi Panti Asuhan.

Program ini dilakukan untuk membantu anak-anak yatim piatu yang dhuafa yang tinggal di panti asuhan. Dalam program ini diberikan bantuan logistik kepada 15 panti asuhan yang ada di wilayah Yogyakarta yang sebelumnya telah melalui proses survey terlebih dahulu. Selanjutnya panti asuhan yang terpilih akan memperoleh bantuan dari LAZIS YBW UII sebesar Rp. 750.000 sampai Rp.1.500.0oo per bulan disesuaikan dengan jumlah anak yang tinggal di panti tersebut, dengan kerja sama atau masa perjanjian selama 1 tahun.

\section{Program Bina Usaha Kecil/Angkringan}

Melalui gerakan Zakat Galang Berdikari LAZIS YBW UII melakukan Program Bina Usaha Kecil. Program tersebut merupakan program pendayagunaan zakat ekonomi produktif yang bertujuan membantu masyarakat kurang mampu atau mustahik yang terkendala pada masalah keterbatasan kepemilikan modal usaha atau modal peralatan untuk berdagang angkringan. 
Mustahik yang direkrut dalam program ini sebanyak 20 orang mustahik yang aktif beribadah dalam kegiatan masjid. Para mustahik yang dipilih telah melalui proses seleksi dan survey lapangan. Selanjutnya mustahik menjalankan usaha "Angkringan Sehat Barokah" yang menitik beratkan pada faktor kesehatan makanan, kehalalan, dan kebersihan lingkungan sekitar. Fasilitas yang diperoleh pada program tersebut berupa 1 unit gerobak angkringan senilai 1,9 juta dan peralatan angkringan lengkap, ditambah modal awal sebesar Rp. 300.000.

\section{Program Peternak MASTER (Mandiri Sejahtera)}

Ternak Master LAZIS UII adalah sebuah program pemberdayaan dengan dukungan dana zakat. Pada awalnya program pemberdayaan yang dirintis pada tahun 2004 ini bernama Qurban Plus yang kemudian terus mengalami perbaikan dari sisi konsep maupun teknis pelaksanaan hingga berubah nama menjadi Ternak Master (Mandiri Sejahtera). Harapannya dari Ternak Master ini akan tumbuh peternak yang profesional, dan dapat menggerakkan perekonomian desa hingga menjadi sentra ternak unggul yang berfungsi sebagai daerah pemasok ternak.

Para peternak Master mendapatkan serangkaian pembinaan dan pendampingan yang meliputi pembinaan spiritual, sedangkan untuk pembinaan teknik beternak dan masalah kesehatan ternak LAZIS YBW UII bekerjasama dengan pihak pemerintah dan pihak lain yang concern terhadap masalah peternakan kambing. Sampai saat ini program Ternak Master LAZIS YBW UII sudah ada di empat cabang sebagaimana tabel 6.

Tabel 5. Sistem Peternakan Master

\begin{tabular}{|c|c|c|}
\hline $\begin{array}{c}\text { Sistem } \\
\text { Pete makan }\end{array}$ & $\begin{array}{c}\text { Keuntungan bagi } \\
\text { peternak }\end{array}$ & Keterangan \\
\hline Penggemukan & $\begin{array}{c}\text { Bagi hasil penjualan } \\
\text { ternak }\end{array}$ & Untuk menyuplai kebutuhan Idul Adha \\
\hline Gaduh & $\begin{array}{c}\text { Bagi hasil berupa } \\
\text { anak kambing hingga } \\
\text { usia sapih }\end{array}$ & $\begin{array}{c}\text { Sebagai usaha pengembangbiakan, serta } \\
\text { menghasilkan bibit/anakan kambing } \\
\text { yang berkualitas }\end{array}$ \\
\hline
\end{tabular}

Dari ke empat cabang program Ternak Master LAZIS YBW UII, cabang di Dusun Babadan Girikerto Turi Sleman dianggap paling berhasil. Modal awal yang diberikan kepada peternak yang tergabung pada kelompok ternak kambing "Handayani" berupa modal pembelian kambing sebanyak 29 ekor sebesar Rp. 45.000.000 dan Rp. 15.000.000 untuk pembuatan kandang kambing, kini para peternak tersebut telah berhasil mengembalikan modal bergulir sebesar Rp.45.000.00o juta tepat pada waktunya selama 2,5 tahun, selain itu para peternak telah menikmati hasilnya, dalam kurun waktu tersebut total anak kambing yang berhasil didapatkan sebanyak 191 ekor. Mereka juga memiliki kas kelompok yang didapat dari hasil limbah ternak penjualan kotoran dan urin kambing kurang lebih Rp. 750.0oo setiap bulan. Selain bantuan modal kambing dan kandang, LAZIS YBW UII juga memberikan bantuan berupa mesin bubut pencacah pakan kambing. 
Tabel 6. Cakupan Program Master

\begin{tabular}{|c|c|c|c|}
\hline No & Cluster & Area & Konsentrasi \\
\hline 1 & $\begin{array}{c}\text { Ternak } \\
\text { Master I }\end{array}$ & $\begin{array}{l}\text { Dusun Sabrang } \\
\text { Wetan Sintokan, } \\
\text { Wukirsari, } \\
\text { Cangkringan, } \\
\text { Sleman }\end{array}$ & $\begin{array}{c}\text { Peternakan } \\
\text { domba untuk } \\
\text { kebutuhan aqiqah dan } \\
\text { Idul Adha }\end{array}$ \\
\hline 2 & $\begin{array}{c}\text { Ternak } \\
\text { Master II }\end{array}$ & $\begin{array}{c}\text { Dusun Bandut Lor, } \\
\text { Argorejo, Sedayu, } \\
\text { Bantul }\end{array}$ & $\begin{array}{l}\text { Peternakan kambing } \\
\text { domba secara gaduh }\end{array}$ \\
\hline 3 & $\begin{array}{l}\text { Ternak } \\
\text { Master } \\
\text { III }\end{array}$ & $\begin{array}{l}\text { dusun Wunut, } \\
\text { Jetis, dan } \\
\text { Pancoran } \\
\text { Selopamioro } \\
\text { Imogiri Bantul. }\end{array}$ & $\begin{array}{c}\text { Peternakan kambing } \\
\text { domba dan Jawa/Bligon }\end{array}$ \\
\hline 4 & $\begin{array}{l}\text { Ternak } \\
\text { Master } \\
\text { IV }\end{array}$ & $\begin{array}{l}\text { Dusun Babadan, } \\
\text { Girikerto, Turi, } \\
\text { Sleman. }\end{array}$ & $\begin{array}{c}\text { Peternakan kambing PE } \\
\text { (Peranakan Etawa) } \\
\text { untuk } \\
\text { pengembangbiakan / } \\
\text { pembibitan dengan } \\
\text { kandang terpadu / } \\
\text { terpusat. }\end{array}$ \\
\hline
\end{tabular}

Menurut keterangan ketua kelompok ternak kambing Handayani, Yudi Purwanto mengatakan bahwa berkat bantuan dan pembinaan dari LAZIS YBW UII, kini sentra ternak di dusun tersebut mulai terkenal lagi setelah lama tertidur. "Dulu dusun kami terkenal dengan peternakan sapi tapi terus melemah dan bubar. Kini harapan baru muncul, setelah ada peternakan kambing PE (Peranakan Etawa). Karena hasil dari peternakan kambing cukup membantu ekonomi warga dusun Babadan". ${ }^{12}$

\section{Program SOSDAK (Sosial, Dakwah dan Kemanusiaan)}

Program pendistribusian zakat dan infak untuk bidang Sosial, Dakwah dan Kemanusiaan sifatnya hanya insidental. Bidang sosial diarahkan untuk membantu kesulitan mustahik yang sifatnya mendesak seperti biaya pengobatan, biaya hidup cuma-cuma dan lain sebagainya.

Selain itu terdapat kegiatan sosial yang dirancang khusus seperti bakti sosial/bazaar sembako murah di bulan Ramadhan, bantuan pembangunan instalasi air di Dusun Watuadeg Cangkringan Sleman dan bantuan air bersih/tangki bagi warga korban erupsi Gunung Merapi. Sedangkan bidang dakwah di antaranya meliputi bantuan pembangunan masjid sebanyak 31 masjid, kegiatan pengajian, kegiatan dakwah mahasiswa.

Bidang kemanusiaan diarahkan untuk membantu korban bencana alam baik nasional maupun internasional seperti bantuan pangan dan dana pembangunan rumah sakit di Gaza Palestina yang disalurkan melalui lembaga Sahabat Al Aqso dan Mer-C Indonesia. 
Selain program-program di atas, LAZIS YBW UII telah membentuk sahabat LAZIS dengan merekrut para relawan dari kalangan mahasiswa yang kebanyakan berasal dari UII, mereka bertugas untuk melakukan aktivitas survey lapangan, pendampingan masyarakat, dan terjun dalam berbagai aktifitas sosial kemasyarakatan. Selain itu para relawan tersebut dibekali dengan berbagai macam pelatihan yang dapat meningkatkan karakter building dan kemampuan mereka.

\begin{tabular}{|c|c|c|c|c|c|}
\hline & Tahun & 2011 & 2012 & 2013 & 2014 \\
\hline \multicolumn{2}{|c|}{ Penghimpunan } & $\begin{array}{c}809.222 .7 \\
00\end{array}$ & $\begin{array}{c}1.118 .231 .10 \\
4\end{array}$ & $\begin{array}{c}915.678 .0 \\
40\end{array}$ & $\begin{array}{c}1.623 \cdot 533 \\
795\end{array}$ \\
\hline \multirow{5}{*}{ 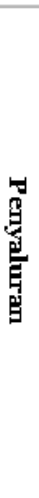 } & Pendidikan & $\begin{array}{c}344.964 .90 \\
\circ\end{array}$ & 409.324 .800 & $\begin{array}{c}460.686 .00 \\
0\end{array}$ & $\begin{array}{c}831.000 .00 \\
0\end{array}$ \\
\hline & $\begin{array}{l}\text { Pemberdayaan } \\
\text { Ekonomi }\end{array}$ & $\begin{array}{c}147.250 .00 \\
0\end{array}$ & 63.500 .000 & 14.875 .000 & - \\
\hline & $\begin{array}{l}\text { Sosial, } \\
\text { Dakwah, } \\
\text { Kemanusiaan }\end{array}$ & 225.121 .820 & 303.454 .350 & 219.133 .150 & $\begin{array}{c}466.079 .75 \\
0\end{array}$ \\
\hline & $\begin{array}{l}\text { Operasional } \\
\text { (Amil dan } \\
\text { Program) }\end{array}$ & 84.816 .920 & 99.095 .158 & 113.277 .917 & $\begin{array}{c}147.403 .49 \\
8\end{array}$ \\
\hline & $\begin{array}{l}\text { Jumlah Total } \\
\text { Penyaluran } \\
\text { Zakat }\end{array}$ & $\begin{array}{c}802.153 .64 \\
\circ\end{array}$ & $775 \cdot 347.308$ & $\begin{array}{c}807.972 .00 \\
7\end{array}$ & $\begin{array}{c}1.444 .4^{8} 3.2 \\
48\end{array}$ \\
\hline
\end{tabular}

Di luar program-program lembaga LAZIS YBW UII, yaitu berkaitan dengan hubungan antara BAZNAS, LAZ maupun Kementerian Agama memiliki dinamika tersendiri. Bila di daerah lain pasca diterbitkannya UU Nomor 23 Tahun 2011 cukup menimbulkan gejolak bagi lembagalembaga pengelola zakat, namun khusus di Yogyakarta diakui oleh Zaenal Ahmad Zakse Staf Divisi Pengembangan Ekonomi Produktif dan Pendidikan LAZIS YBW UII cukup berbeda, karena hubungan antara BAZNAS, LAZ maupun Kementerian Agama masih cukup mesra, namun menurutnya LAZ di Yogyakarta masih bersifat menunggu kejelasan karena belum ada sosialisasi lagi dari Kanwil Kementerian Agama terkait pengurusan perizinan. ${ }^{13}$

\section{Kinerja LAZIS Masjid Syuhada}

LAZIS Masjid Syuhada bernaung di bawah Yayasan Masjid Syuhada (YASMA) yang berakte notaris No. 30 tanggal 7 Februari 2011, dan telah tercatat sebagai lembaga resmi dan sah. Pengesahan pendirian LAZIS Masjid Syuhada oleh YASMA sesuai dengan SK pengurus YASMA dengan Nomor; 28/Kep/YASMA/2004 pada tanggal 21 Agustus 2004.

Secara historis, Masjid Syuhada sendiri merupakan masjid bersejarah pemberian Presiden Sukarno kepada kaum muslimin Yogyakarta yang dibangun pada tahun 1950. Sesuai namanya Syuhada berarti Pahlawan, sebagai monumen penghargaan kepada para pahlawan yang gugur syahid mempertahankan proklamasi kemerdekaan RI. Selain itu juga untuk memenuhi kebutuhan ibadah masyarakat muslim Yogyakarta. ${ }^{14}$ 
Secara garis besar, lingkup kegiatan Masjid Syuhada (di bawah kendali YASMA) adalah di bidang pendidikan dan dakwah. Untuk bidang pendidikan, ada yang bersifat formal, dan ada yang non formal. Adapun di bidang dakwah, pola pergerakannya menggunakan pendekatan ekonomi, budaya, dan pemberdayaan sosial. Untuk menjalankan misi dan pola pengelolaan pergerakannya, di lingkungan Masjid Syuhada telah didirikan lembaga-lembaga penunjang (formal dan non formal) yang berada dalam naungan Yayasan Masjid dan Asrama (YASMA) Syuhada. Untuk kegiatan-kegiatan yang tidak terwadahi oleh lembaga-lembaga tersebut, dibentuklah kepanitiaan

Tabel 8. Penerimaan ZISWaf Masjid Syuhada Tahun 2010 s.d 2014

\begin{tabular}{|c|c|c|c|c|c|}
\hline \multirow{2}{*}{$\begin{array}{c}\text { Penerima } \\
\text { an }\end{array}$} & \multicolumn{5}{|c|}{ Tahun } \\
\hline & 2010 & 2011 & 2012 & 2013 & 2014 \\
\hline \multirow{2}{*}{ Zakat Maal } & 108.405 .0 & 198.625 .20 & 310.465 .49 & 346.890 .7 & 326.799 .8 \\
\hline & oo & o & 4 & 80 & 76 \\
\hline Zakat & 10625710 & 27.787 .750 & 25.888 .150 & 33.292 .90 & 39.982 .25 \\
\hline Fitrah & $19.050 \cdot / 10$ & $2, .70 / .150$ & & 0 & 0 \\
\hline \multirow{2}{*}{ Infaq } & 132.171 .85 & 105.823 .40 & 208.066 .9 & 262.515 .3 & 469.032 .0 \\
\hline & $\mathrm{O}$ & $\mathrm{O}$ & 50 & 00 & 50 \\
\hline \multirow{2}{*}{ Qurban } & - & - & 17.150 .000 & 31.250 .00 & 91.200 .00 \\
\hline & & & & 0 & \\
\hline Wakaf & 2.776 .000 & 6.400 .000 & 12.455 .000 & 29.654 .50 & 5.450 .000 \\
\hline \multirow{2}{*}{ Fidyah } & - & - & 11639000 & 15.804 .80 & 14.310 .00 \\
\hline & - & & & o & o \\
\hline \multirow{2}{*}{ Jumlah } & 262.988 .5 & 338.636 .35 & 585.664 .59 & 719.408 .2 & 946.774 .17 \\
\hline & 60 & & 1 & 80 & \\
\hline
\end{tabular}

$a d$

hoc

lang

sung

di

baw

ah

kord inasi

Yaya

san,

sepe

rti

Kep

anitiaan Ramadhan dan Kepanitiaan Qurban. 
Sudah bertahun-tahun lamanya, semenjak belum populernya lembaga amil zakat, banyak umat islam baik dari daerah Yogyakarta maupun dari luar daerah yang menitipkan zakatnya ke Masjid Syuhada. Pada tahun-tahun itu, titipan zakat dari masyarakat dilayani oleh panitia penerimaan zakat sebagai salah satu divisi dalam kepanitiaan ramadhan. Karena hanya ditangani oleh kepanitiaan ad hoc, maka pelayanan dan pengelolaan zakat tidak dapat berkesinambungan. Kebutuhan akan hadirnya lembaga amil zakat makin hari kian terasa, terlebih supaya program pemberdayaan zakat dapat berkesinambungan.

Pada tahun 2005, Muhamad Ansori yang merupakan alumnus Asrama YASMA dan mantan Direktur PKMS tahun 2000-2003, berinisiatif mengajukan proposal pendirian Lembaga Amil Zakat di lingkungan Masjid Syuhada yang dipresentasikan pada rapat pengurus harian YASMA. Gayung pun bersambut, usulan tersebut disetujui oleh forum rapat YASMA. Kebetulan pada saat itu YASMA punya program membeli rumah keluarga Ibu Zainal yang posisinya berhadapan persis dengan Masjid Syuhada.

Maka pada bulan Juli 2005, keluarlah SK YASMA tentang pembentukan lembaga amil zakat di lingkungan Masjid Syuhada, yang dinamai LAZIS Masjid Syuhada, dan sebagai inisiator, Muhamad Ansori ditugaskan membidani pendirian lembaga tersebut, sekaligus menjabat sebagai Direktur yang pertama.

Sekretariat Kantor LAZIS Masjid Syuhada berada di Komplek Masjid Syuhada ; Jl. I Dewa Nyoman Oka 28 Kota Baru Yogyakarta Telp/fax. 0274- 543500, email : lazismasjidsyuhada27@yahoo.co.id, Website : www.lazismasjidsyuhada.com.

LAZIS Masjid Syuhada memiliki visi : "Menjadi Lembaga Amil Zakat, Infak, dan Shadaqah (LAZIS) yang amanah, profesional, akuntabel \& Kebanggaan ummat dalam rangka Pemberdayaan Dhu'afa”. Dengan misi ; Mengoptimalkan kualitas pengelolaan ZIS yang amanah dan profesional; Mengoptimalkan potensi/pemberdayaan Umat melalui Zakat Infaq Shadaqah \& Wakaf (ZISWAF); Membantu muzaki dalam menyalurkan ZIS-nya kepada masyarakat; dan Memberdayakan masyarakat (mustahik), dalam bidang Ekonomi, Pendidikan, Kesehatan, Dakwah dan sosial menuju masyarakat religius, sehat, sejahtera dan Mandiri.

Tujuan berdirinya LAZIS Masjid Syuhada adalah: Meningkatkan kesadaran ber-ZIS bagi masyarakat; Meningkatkan perolehan dana ZIS dan asset produktif; Meningkatkan kualitas, profesionalitas dan akuntabilitas Sumber Daya Amil; Memberdayakan mustahik menjadi Muzakki. LAZIS Masjid Syuhada dibentuk oleh Yayasan Masjid Syuhada (YASMA), yang berkedudukan di DI Yogyakarta, merupakan satu lembaga yang bersifat semi independen, netral, tidak berpolitik dan non-diskriminatif.

Dengan memegang Motto “Sucikan Harta, Berdayakan Dhu'afa”, LAZIS Masjid Syuhada mempunyai lingkup kerja di wilayah DI Yogyakarta. Penghimpunan dana dilakukan pada wilayah yang telah ditentukan sebagai basis operasional LAZIS Masjid Syuhada, akan tetapi sangat dimungkinkan untuk menghimpun dana dari muzakki di luar wilayah tersebut, selama para 
muzakki merasa lebih amanah dengan menyerahkan dana/zakatnya kepada LAZIS MS. Juga terbuka peluang untuk menghimpun dana/zakat dari lembaga donor atau perusahaan.

Penyaluran dana dilakukan hanya pada mustahiq/dhuafa' yang berdomisili di wilayah operasional LAZIS Masjid Syuhada. Hanya dalam kondisi khusus dan pada kasus-kasus tertentu, LAZIS Masjid Syuhada dapat menyalurkan bantuannya di luar wilayah operasionalnya, atau apabila kemiskinan di wilayah operasional LAZIS Masjid Syuhada sudah tertanggulangi dengan baik, lembaga dapat menyalurkan bantuannya ke luar wilayah operasionalnya.

Dari tabel 8 di atas dapat diketahui bahwa pengumpulan dana infaq yang dikumpulkan oleh LAZIS Masjid Syuhada pada tahun 2014 lebih menonjol dibandingkan dengan pengumpulan dana zakat maupun dana lainnya.

\section{Analisis}

Faktor-faktor yang menjadi pendukung dalam keberhasilan pengelolaan zakat dapat dilihat dari beberapa tinjauan, seperti:

1) Bila ditinjau dari segi geografis, wilayah provinsi merupakan wilayah yang tidak terlalu luas untuk ukuran sebuah provinsi di Indonesia, sehingga hal ini bisa menjadi faktor pendukung dalam memudahkan konsolidasi dan integrasi program di antara BAZNAS dan LAZ, hal tersebut telah dilakukan oleh pihak kesultanan Yogyakarta melalui sarana pengajian rutin bulanan yang melibatkan unsur instansi pemerintah dan ormas-ormas Islam, termasuk di dalamnya lembaga pengelola zakat.

2) Sementara dilihat secara sosio-kultural, mayoritas masyarakat muslim DI Yogyakarta merupakan masyarakat yang memiliki karakter religius, menjaga adat istiadat tata kerama dan penghargaaan yang tinggi terhadap kalangan priyayi keraton dan para ulama sebagai simbol pemimpin kultural mereka, sehingga petuah-petuah Sultan maupun pesan-pesan keagamaan para ulama akan mudah didengar dan dilaksanakan oleh masyarakat. Sementara itu Yogyakarta yang terkenal sebagai kota pelajar juga melahirkan kalangan akademisi yang banyak memberikan pemikiran dan konstribusi terhadap kemajuan perzakatan di Yogyakarta, seperti tumbuhnya lembaga-lembaga zakat yang tumbuh di lingkungan perguruan tinggi semisal berdirinya LAZIS YBW UII. Serta Tumbuhnya kesadaran berzakat di kalangan masyarakat muslim kelas ekonomi menengah juga memberikan dampak yang cukup signifikan dalam perolehan dana zakat.

3) Ditinjau dari segi sejarah, Yogyakarta sebagai wilayah yang pernah mengalami berbagai musibah yang berskala nasional seperti Gempa Bumi Yogyakarta yang terjadi tahun 2006 dan Erupsi Gunung Merapi yang terjadi tahun 2010, hal tersebut membangkitkan ghiroh dan kesadaran masyarakat untuk saling membantu dan menolong kesulitan orang lain yang diwujudkan dalam bentuk zakat, infaq dan shodaqoh yang disalurkan melalui lembagalembaga pengelola zakat. 
4) Tumbuhnya semangat dan kepedulian kalangan umat Islam untuk menyelamatkan akidah kaum dhuafa muslim akibat adanya aktifitas sosial yang dilakukan oleh lembaga-lembag atau tempat ibadah umat agama lain, berupa bantuan sembako atau pasar murah yang menyasar kepada para fakir miskin dan kaum dhuafa.

Sementara dilihat dari kendala pengumpulan zakat di Provinsi DI Yogyakarta di antaranya adalah;

1) Belum adanya regulasi berupa Peraturan Daerah di tingkat provinsi. Baru beberapa kabupaten yang memiliki perda terkait penghimpunan dana zakat, sehingga apa yang dilakukan oleh BAZNAS Provinsi dan Kab/Kota dan LAZ selama ini belum dirasa efektif dan mempunyai greget bagi masyarakat secara luas.

2) Kenyataan di mana-mana BAZNAS Kab/Kota baru menganjurkan pengumpulan zakat baru sekitar PNS saja, sementara yang bukan PNS masih sangat sedikit.

3) Sikap menunggu dari LAZ di DI Yogyakarta akibat belum ada sosialisasi lagi dari Kanwil Kementerian Agama terkait pengurusan perizinan.

\section{Simpulan}

Dari berbagai uraian di atas dapat diambil beberapa kesimpulan sebagai berikut:

(1) Keterbatasan SDM dan sarana prasarana yang dimiliki BAZNAS Provinsi DI Yogyakarta serta lemahnya keterlibatan dan dukungan dari pejabat di tingkat provinsi DI Yogyakarta membuat BAZNAS Provinsi belum dapat menjalankan tugas dan fungsinya secara optimal, bahkan justru BAZNAS tingkat Kota Yogyakarta dianggap lebih berhasil dalam hal optimalisasi pengumpulan zakat. LAZ-LAZ yang ada di DI Yogyakarta umumnya berskala Nasional dan Provinsi, yang dibentuk oleh ormas, perguruan tinggi, yayasan keagamaan atau perkumpulan anggota masyarakat. Pengdistribusian dan Pendayagunaan dana zakat, infaq dan shodaqoh disalurkan dalam berbagai program seperti: bantuan pendidikan, bantuan ekonomi produktif, bantuan dakwah, pembinaan muallaf, dan bantuan pinjaman tanpa bunga.

(2) Lembaga-lembaga zakat di DI Yogyakarta yang belum berizin umumnya telah mempersiapkan diri dengan melakukan upaya ke arah legalisasi lembaga pengelola zakat sesuai UU Zakat No. 23 Tahun 2011, dengan pengajuan rekomendasi ke BAZNAS DI Yogyakarta akan tetapi struktur kepengurusan BAZNAS Provinsi DI Yogyakarta yang saat ini sedang dalam masa transisi dianggap menjadi kendala utama dalam proses pengajuan izin legalisasi LAZ. Walaupun di Yogyakarta tidak terdapat gejolak di antara pengelola LAZ pasca terbitnya UU No 23 tahun 2011, namun saat ini relasi antara BAZNAS dan LAZ belum terbangun secara efektif formal kelembagaan, sehingga masih terdapat kesenjangan antara BAZNAS dan LAZ baik dari segi kesefahaman maupun praktik pengelolaan zakat yang masih berjalan sendiri-sendiri. 


\section{Catatan Kaki}

${ }^{1}$ Islam dibangun di atas lima perkara: bersaksi bahwa tidak ada ilah (sesembahan) yang berhak disembah melainkan Allah dan Muhammad adalah utusan-Nya; menegakkan shalat; menunaikan zakat; menunaikan haji; dan berpuasa di bulan Ramadhan.” (HR. Bukhari no. 8 dan Muslim no. 16)

${ }^{2}$ Dalam hal ini dapat diartikan sebagai ibadah di bidang harta yang memiliki kedudukan yang sangat penting dalam membangun masyarakat.

3 Ataina Hudayati dan Acmad Tohirin, 2010. Management of Zakah: Centralised VS Decentralised Approach, Seventh International Conference--The Tawhidi Epistemology: Zakat and Waqf Economy, Bangi. hal. 352. Lihat juga Muhammad Lubis; Nurul Ibtisam Yaacob; Yusoff Omar dan Dahlan, Abdurrahman A. 2011. Enhancement Of Zakat Distribution Management System: Case Study In Malaysia, Conference Paper in International Management Conference, Malaysia (IMAC) 2011,. Hal. 1

4 Rowan Popplewell and Rachel Hayman. "Where, How and Why are Action Research Approaches used by International Development Non Govermental Organisations?” dalam INTRAC Briefing Paper 32. 2012. Hal. 1

5 Robert M Davison, Maris G Martinsons and Ned Kock. Principles of Canonical Action Research. Information System Journal, Volume 14 (2004). Hal. 72-73

${ }^{6}$ DI Yogyakarta Dalam Angka Tahun 2014

7 Tidak ada keterangan yang jelas tentang uraian pemuka agama ini misalnya kiyai, ustadz atau mubaligh.

${ }^{8}$ Wawancara dengan Juni A. Dwi Utomo sebagai pengurus Forum Zakat (FOZ) DI Yogyakarta, pada FGD di Kantor Wilayah Kementerian Agama DI Yogyakarta, tanggal 12 Agustus 2015

9 Wawancara dengan Muhammmad Yusuf Wibison, Kabid Pendistribusian dan Pendayagunaan BAZIS DI Yogyakarta, tgl 5 Agustus 2015 di Yogyakarta.

10 Wawancara dengan Muhammmad Yusuf Wibison, Kabid Pendistribusian dan Pendayagunaan BAZIS DI Yogyakarta, tgl 5 Agustus 2015 di Yogyakarta.

${ }^{11}$ Hasil Wawancara dengan HM. Sularno, MA sebagai ketua LAZIS YBW UII, tgl 7 Agustus 2015 di Yogyakarta.

12 Wawancara dengan Yudi Purwanto, Ketua Kelompok Peternak kambing PE "Handayani” di Dusun Babadan Girikerto Turi Sleman, tanggal 9 Agustus 2015.

13 Wawancara dengan Zaenal Ahmad Zakse Staf Divisi Pengembangan Ekonomi Produktif dan Pendidikan LAZIS YBW UII pada FGD di Kanwil Kementerian Agama DIY, tanggal 12 Agustus 2015.

14 Data bersumber dari Sistem Informasi masjid Direktorat Urusan Agama Islam dan Pemberdayaan Syariat Direktorat Jenderal Bimbingan Masyarakat Islam Kementerian Agama RI

\section{DAFTAR PUSTAKA}

Anderson, J.E. 1979. Public Policy Making. New York : Praeger Publisher

Davison, Robert M; Martinsons, Maris G and Kock, Ned. Principles of Canonical Action Research. Information System Journal, Volume 14 (2004), hal. 72-73

Dunn, William N. 1991. Public Policy Analysis an Introduction. New Jersey : Prentice Hall Inc

Hasibuan, Malayu S.P. 2011. Manajemen Dasar, Pengertian, dan Masalah, Jakarta : PT Bumi Aksara

Huda, Nurul; Anggraini, Desti; Mardoni, Khalifah Muhamad Ali Yosi dan Rini, Nova. Prioritas Solusi Permasalahan Zakat dengan Metode AHP (Studi di Banten dan Kalimantan Selatan), Jurnal Ilmu Ekonomi Syariah Al Istishad, Vol VI No. 2 Tahun 2014.

Hudayati, Ataina, dan Tohirin, Achmad. 2010. "Management of Zakah: Centralised VS Decentralised Approach", Seventh International Conference-The Tawhidi Epistemology: Zakat and Waqf Economy, Bangi.

Kholis, Nur; Sobaya, Soya; Andriansyah, Yuli dan Iqbal, Muhammad. Potret Filantropi Islam Di Propinsi Daerah Istimewa Yogyakarta, Jurnal La Riba, Volume VII, No. 1 Juli 2013

Latief, Hilman. 2008. Membangun Koherensi Antar Sektor : Filantropi Islam, Agenda Organisasi Sektor Ketiga dan Masyarakat Sipil di Indonesia, Zakat \&Empowering, Jurnal Pemikiran dan Gagasan, Volume 1 Sya'ban 1429/Agustus 2008.

Lindblom, Charles E. 1968. The Policy Making Process. New Jersey : Prentice Hall Inc

Lubis, Muhammad; Yaacob, Nurul Ibtisam; Omar, Yusoff dan Dahlan, Abdurrahman A. 2011. "Enhancement Of Zakat Distribution Management System: Case Study In Malaysia", Conference Paper in International Management Conference, Malaysia (IMAC) 2011

Mahmudi. 2009. "Penguatan Tata Kelola dan Reposisi Kelembagaan Organisasi Pengelola Zakat", Hasil Riset dipresentasikan dalam Simposium Nasional IV Sistem Ekonomi Islam "Strengthening Institutions on Islamic Economic System", 8 - 9 Oktober 2009 Yogyakarta.

Mazmanian, Daniel A. and Sabatier, Paul A. 1983. Implementation And Public Policy. New Jersey : Scott, Foresmann and Company 
Popplewell, Rowan and Hayman, Rachel. "Where, How and Why are Action Research Approaches used by International Development Non Govermental Organisations?” dalam INTRAC Briefing Paper 32. 2012.

Rofiq, Ahmad. 2010. Kompilasi Zakat, Semarang : Balai Penelitian dan Pengembangan Agama Semarang, Kementerian Agama RI

Subasman, Iman. 2011. Analisis Implementasi Kebijakan Undang-Undang 38 Tahun 1999 tentang Pengelolaan Zakat (Studi Pengelolaan Zakat di Kota "Zakat Award" Tingkat Nasional 2010), dalam kumpulan penelitian berjudul Rekonseptualisasi dan Restrukturalisasi Pelayanan Keagamaan di Indonesia, Penelitian Kompetitif Kehidupan Keagamaan Tahun 2011, Pusat Kehidupan Keagamaan, Kementerian Agama RI 